Natural Hazards and Earth System Sciences (2003) 3: 561-568

(C) European Geosciences Union 2003

Natural Hazards
and Earth
System Sciences

\title{
Slope instability in the Bastardo Basin (Umbria, Central Italy) - The landslide of Barattano
}

\author{
C. Cencetti and P. Conversini \\ Civil and Environmental Engineering Department, University of Perugia, Via G. Duranti, 93, I-06125 Perugia, Italy
}

Received: 7 October 2002 - Revised: 7 March 2003 - Accepted: 23 May 2003

\begin{abstract}
The Bastardo Basin is one of the classics Apenninic intermontane basins of central Italy. They are enclosed tectonic basins (graben and semigraben) with high anthropization, but with high vulnerability, too (seismic, hydrogeological and geomorphological).

The paper concerns some aspects about slope instability in the Bastardo Basin as part of a wider research, which aims to actually define the characteristics of the liability to landslides of the Apenninic intermontane basins. In particular lithological, stratigraphical and hydrogeological conditions are analysed under which a landslide near village of Barattano has developed.
\end{abstract}

This mass movement, at different times, produced partial or total occlusion of the torrent Puglia. Here geognostic investigations together with laboratory tests and subsequent monitoring of landslide area were carried out.

A back analysis, based on limit equilibrium solutions for the factor of safety of the slope, provided the residual strenght properties of the soil mass along the sliding surface.

The landslide of Barattano is representative of a very frequent situation (in terms of type, factors and causes of the movement, possible development of the movement) not only within Bastardo Basin, but in general within Apenninic intermontane basins, too.

The study of landslide and the design of appropriate remedial measures are of great importance in terms of prevention and mitigation of geologic-hydraulic risk in Apenninic intermontane basins.

\section{Introduction}

Nowadays, the Apenninic intermontane basins in central Italy form wide alluvial plains, whose structural origin (graben or semi-graben) dates back to the Upper Pliocene - Lower Pleistocene as the result of the extensive tectonic phase, which, from that period has often involved - and still

Correspondence to: P. Conversini (pconver@unipg.it) does involve - the Tyrrhenian slope of the Apenninic Chain (Barchi et al., 1991).

The principal settlements, together with the road, economic and industrial infrastructures of central Italy, have all been concentrated in these areas.

The strategic importance of the latter is in direct contrast with their great geological vulnerability:

1. they are areas of high seismic activity, linked with the tectonic, extensive-type stress field, which is still active in this part of the chain;

2. they are areas in which the concentration of anthropic activities (agricultural, zoo-technical, industrial and commercial) forms a serious threat to the hydrogeological potential and to the quality of the aquifers present in the alluvial areas;

3. the liability to landslides of the slopes which descend gradually towards the plains is increased by the presence of clastic, heterogeneous and often poorly consolidated sediments in continental facies (Villafranchiano Auctorum): these deposits have silted up the structural hollows which, in the Upper Pliocene - Lower Pleistocene, held fairly extensive lacustrine and river-marsh basins.

\subsection{The Bastardo Basin}

The Bastardo Basin (Gregori, 1988), is one of the classical Apenninic intermontane basins in central Italy (Fig. 1).

Measuring approximately $80 \mathrm{~km}^{2}$, it was considered at first to be a gulf in the Ancient Tiberian Lake (the largest of the Upper Pliocene - Lower Pleistocene lakes in central Italy). It has since undergone a partially independent, geological and structural evolution, which can be schematised by the succession of events illustrated in Fig. 2 (from Gregori, 1988).

The stratigraphic filling sequence has been studied in the past and defined by means of deep drilling, in order to iden- 


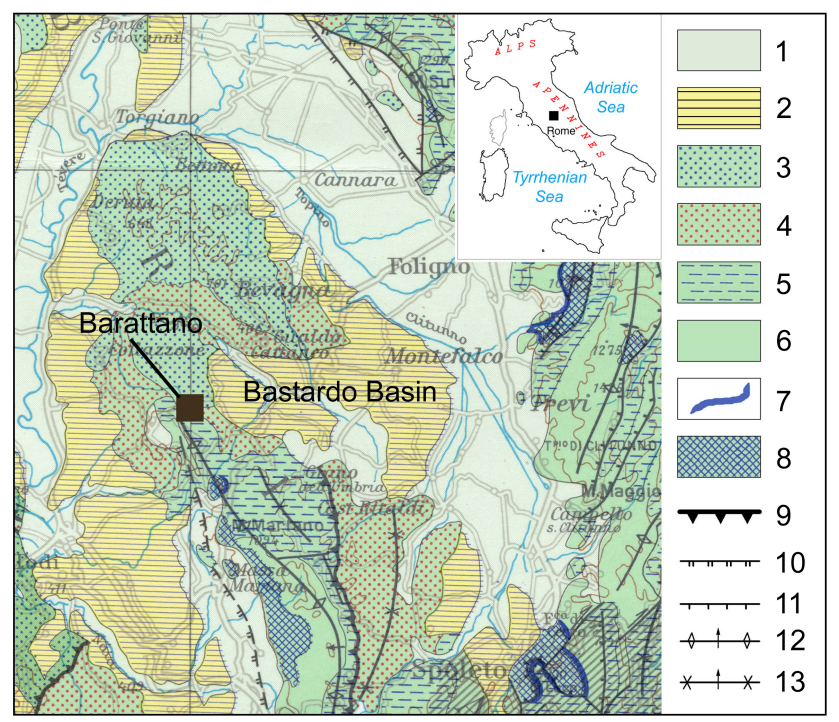

Fig. 1. Geological sketch of central Umbria, Italy (from "Structural Model of Italy" - CNR, 1991). Legenda: 1) Undifferentiated continental deposits (Holocene - Upper Pleistocene); 2) Lacustrine sediments (Villafranchian); 3) Arenaceous - marly turbidites ("Marnoso-Arenacea" Auct.) (Tortonian - Lower Miocene); 4) Hemipelagic marls and marly limestones ("Schlier" Auct.) (Upper - Middle Miocene); 5) Cherty marly limestones, marls, marly limestones, marly clays ("Bisciaro", "Scaglia", "Marne a Fucoidi" Auct.) (Lower Miocene - Lower Cretaceous); 6) Deeper-water cherty limestones and subordinate marls (Lower Cretaceous - Middle Liassic); 7) Pelagic limestones forming condensed sequences on top of Jurassic morphological highs (Upper Jurassic - Middle Liassic); 8) Shallow-water limestones and dolomites forming (Lower Liassic - Upper Triassic); 9) Contact between groups of tectonic units derived from different paleogeographics domains; 10) Normal fault; 11) Overthrust and reverse fault; 12) Axis of anticline (orthogonal arrow indicates the dip of the axial plain); 13) Axis of syncline (orthogonal arrow indicates the dip of the axial plain).

tify and then exploit the levels of lignite, which are frequently found in the area (GE.MI.NA., 1963).

The stratigraphic sequence is, in fact, characterised by clastic deposits in lacustrine and river-marsh facies, the majority of which are fine-grained: to schematise the process, we pass from basal, lignitiferous clays - still the object of quarrying today - to sands with ever-increasing interbeds of gravels at the top of the sequence. In association with the aforementioned sequence, moderately sized, mainly terrigenous travertine plates have been found in a sub-horizontal position in the south-west portion of the basin. These plates do not form unitary and continuous geologic bodies and they are probably related to the upwelling of saturated in $\mathrm{CaCO}_{3}$ waters linked with the tectonic activity of the fault which borders the southern edge of the basin (Fig. 3).

The study of slope instability in the Bastardo Basin is part of a wider research, which aims to actually define the characteristics of the liability to landslides of the Apenninic intermontane basins.

Several natural slopes in the basin are affected by evident

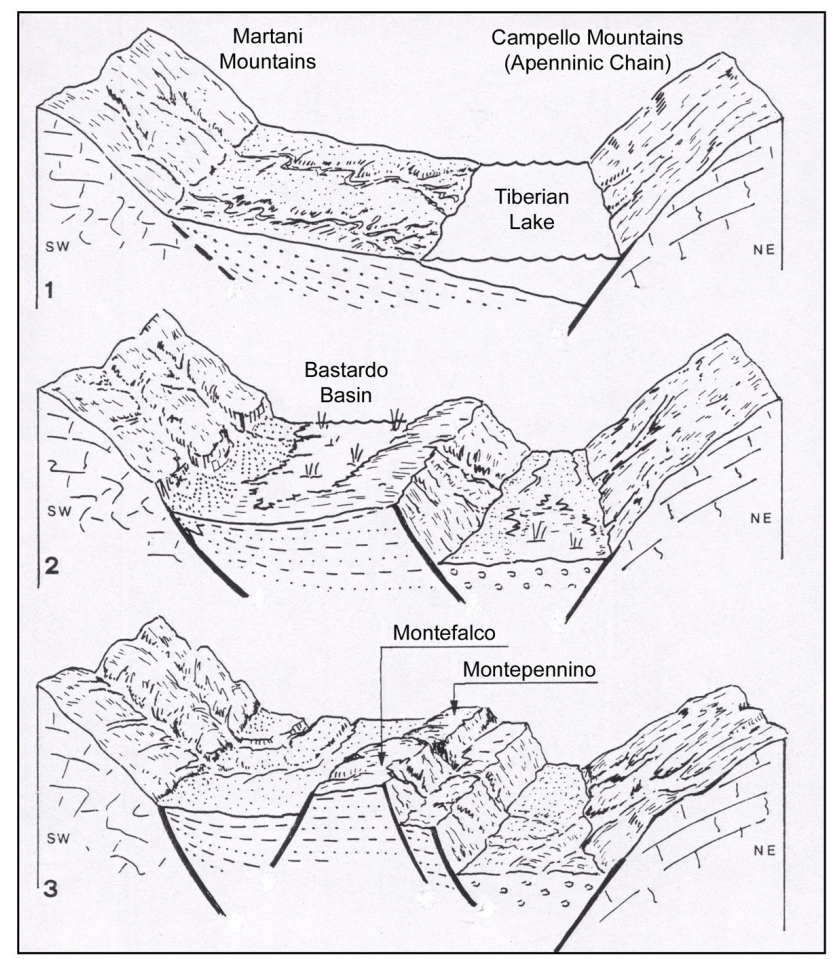

Fig. 2. Evolutional sketch of the Bastardo Basin (from Gregori, 1988). The graben of Tiberian Lake (stage 1, Upper Pliocene) is interested by a normal fault (stage 2, Lower Pleistocene) which produces a tilting towards SW and stop the major streams flowing towards NE; so Bastardo Basin is forming. In the stage 3 (Middle Pleistocene) another extensive tectonic phase affects the area of Bastardo and the Montefalco Horst is rising. Bastardo Basin is drained by torrents Puglia and Attone.

slope movements which interest roads, buildings and other infrastructures, often resulting in serious damage. The great majority of these slope movements can be classified as rotational slides and/or flows. Often they present as composite landslides (WP/WLI, 1993b) due to the combination of the two aforementioned principal failure mechanism.

The landslide of Barattano, located in the heading area of the hydrographic basin of the torrent Puglia, is a typical example of the slope movements which can be observed in the area of Bastardo (i.e. rotational slides/flows - Brown et al., 1992; WP/WLI, 1993a; Cruden and Varnes, 1996; Senneset, 1996). The main interest in this landslide, rather than its extension, lies in the fact that the sliding mass can produce the temporary occlusion of the torrent Puglia, yielding risk conditions which have to be evaluated with care.

As this landslide is considered representative of the types of landslides existing in the area, it has been studied in detail in order to identify movement dynamics, its causes, its future development and the associated geological and hydraulic risk conditions, at the request of the Regione Umbria in 1997 to determine its progression and the risk connected with the damming of the river bed of the torrent Puglia. 


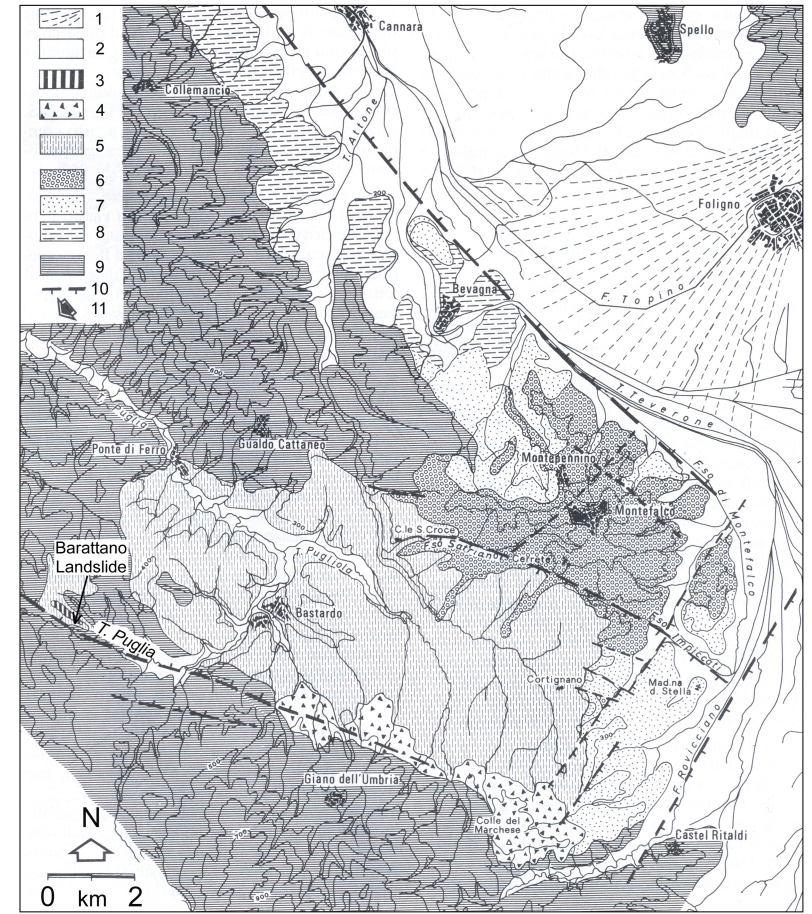

Fig. 3. Geological sketch of the Bastardo Basin (from Gregori, 1988). Legenda: 1) Alluvial fan of River Topino; 2) Recent alluvial sediments of Umbrian Valley; 3) Travertine; 4) Colluvial sediments close to the master fault of Martani Mountains; 5) Bastardo Basin sediments (Lower Pleistocene); Tiberian Lake series (Villafranchian): 6) Conglomerates; 7) Sands; 8) Clays; 9) Prepliocenic bedrock; 10) Normal fault; 11) Direction of tilting.

\section{General features of the liability to landslides in the Bastardo Basin}

Slope instability in the Bastardo Basin is shown by its tendency to landslides, typical of clastic sediments in continental facies.

In fact, although the stratigraphic sequence can be schematised into a coarsening upward sequence of a filled basin, lithotypes of different particle sizes can frequently be seen to alternate with each other.

Although they form the basal part of the aforementioned sequence, the clays, and often lignitiferous levels are also present in the upper members, alternating with deposits which are more obviously made of sands and conglomerates, the latter lying in a lenticular position.

The increase of interstitial pressures on the less permeable layers is such that it produces a decrease in resistance to the shear stress along the surfaces where different lithotypes are in contact with each other. It also triggers two main types of movements: slides (both rotational and translational movement) and flows. Often, in fact, it is just this combination of the two types of movement which produces complex and/or composite landslides (WP/WLI, 1993b; Cruden and Varnes, 1996).

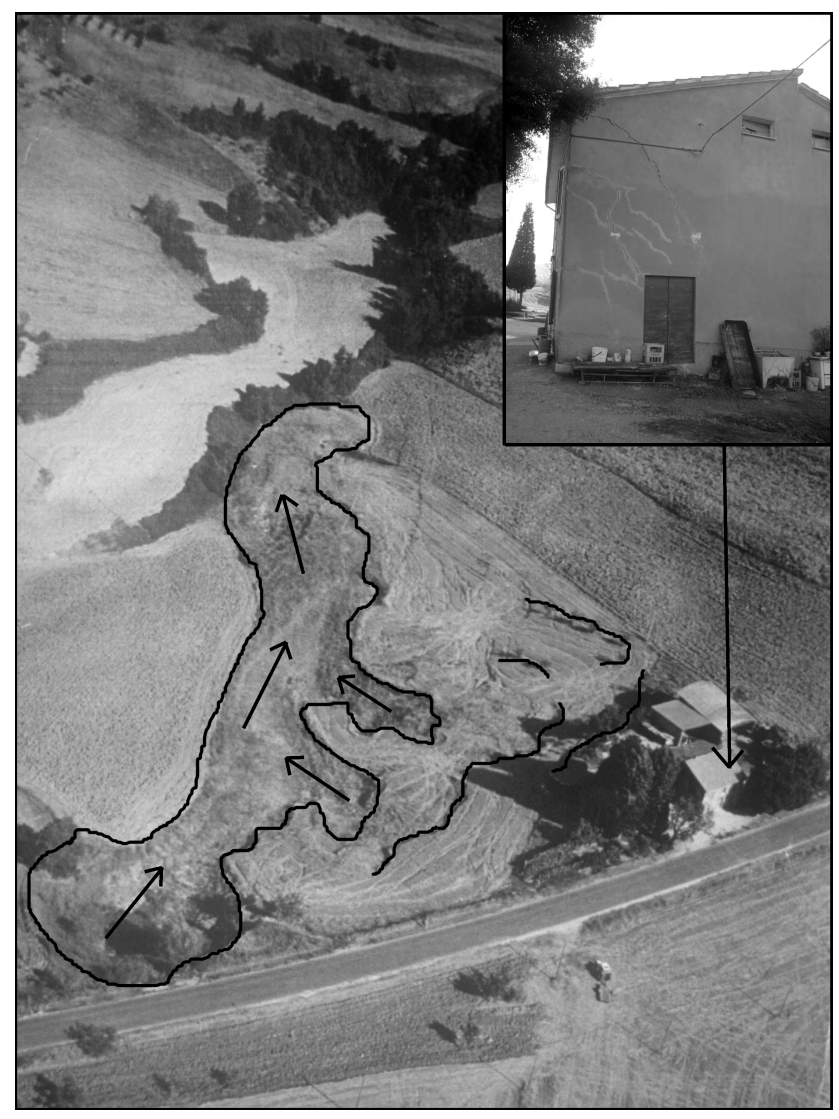

Fig. 4. The flow is the typical mass movement in the Bastardo Basin. In this aerial view you can note a flow interesting the slope near Bivio Saragano, close to the village of Barattano. The direction of the main movements and the crown area, close to the houses, are also indicated. In the frame: a detail of the house (indicated by arrow) seriously damaged by mass movement. You can note the recent deep cracks in the walls and the glasses used as spy in order to monitoring the movements of the structure.

The landslides are frequently superficial, but at times they are quite long (especially flows, Fig. 4), and as a result they often cause unbalance to the buildings and infrastructures involved (Figs. 4-5).

The rapidity of landslide movements, characteristic of this type of landslide, also produces frequent interactions with the dynamics of the river beds, causing either partial or total damming.

It is the case of the landslide near Barattano, on the hydrographic left-hand side of the torrent Puglia, situated in a marginal position of the Basin (Fig. 3).

\section{The Barattano landslide}

A landslide is at present taking place along the left-hand side of the valley of the torrent Puglia, approximately on a level with the village of Barattano in the Commune of Gualdo Cattaneo. This presumably began in the $70 \mathrm{~s}$, as can be deduced from a close examination of aerial photos, belonging to the 


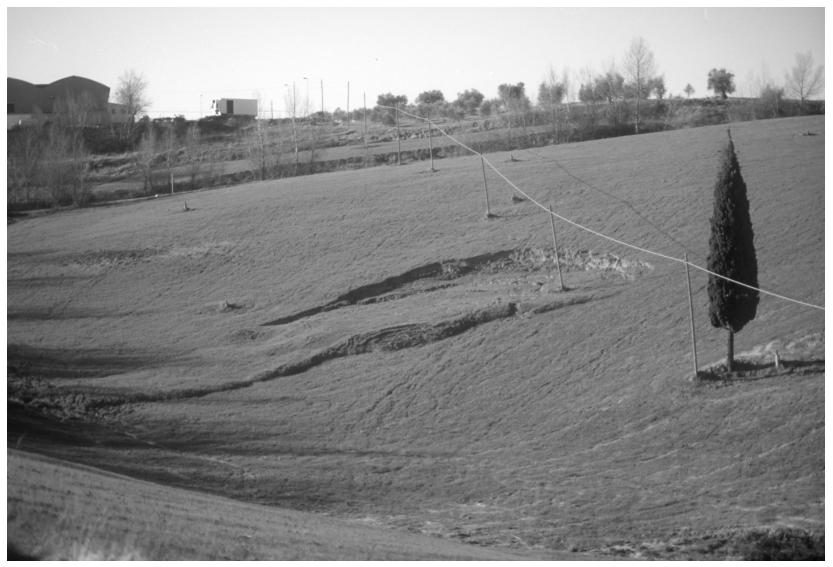

Fig. 5. Another flow with a sliding surface at shallow depth. In spite of their superficial movements, these landslides often produce many damages (in this case an electric line is involved).

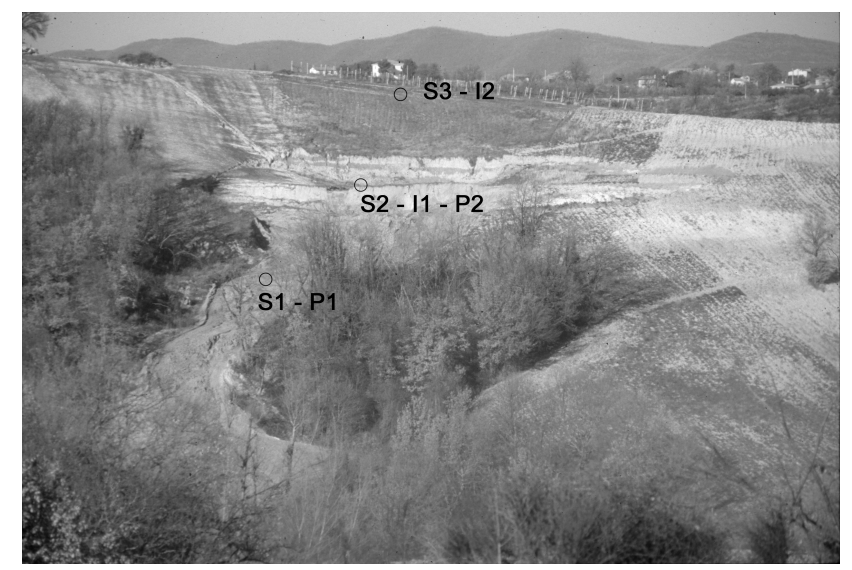

Fig. 6. Panoramic view of the landslide of Barattano. $S_{1}, S_{2}, S_{3}=$ core drillings; $\mathrm{I}_{1}, \mathrm{I}_{2}=$ inclinometers; $\mathrm{P}_{1}, \mathrm{P}_{2}=$ piezometers.

Regione Umbria from the flight made in 1977, in which the morphological features of the landslide are already obvious. It accelerated sharply, however, after 1995 and has led to the retrogression and widening of the landslide main scarp; the main body of the landslide has already reached the bed of the torrent Puglia, thus preventing the normal flow of water (Cencetti et al., 1996).

At present time, the landslide (Figs. 6-9) is about $200 \mathrm{~m}$ in length, with a total area of around $30000 \mathrm{~m}^{2}$ and begins at a height of $410 \mathrm{~m}$ a.s.l. near a narrow ridge. Its lower boundary coincides, as we said before, with the river bed of the torrent Puglia, along which the main body of the landslide has canalised and this has caused total damming of the river bed. The landslide spreads over an area of approximately three hectares.

In 1997, the rapid evolution of the landslide motivated a detailed study of the mass movement with the objective of better defining its characteristics and evaluating the related risk of occlusion of the river bed of the torrent Puglia.

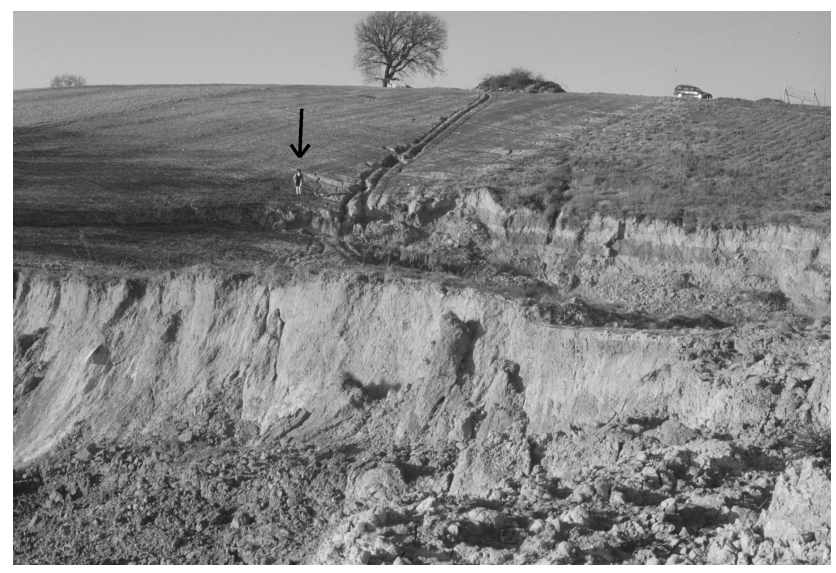

Fig. 7. A detailed view of the main scarp of the Barattano landslide. You can note the man at the top of the scarp (see the arrow) in order to evaluate the real size of the landslide.

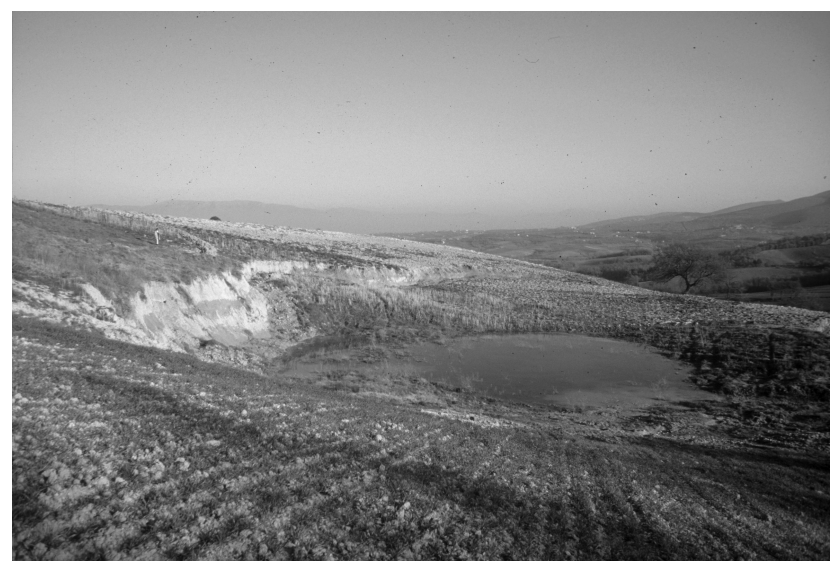

Fig. 8. A lake (it represents the outcropping piezometric surface) is located between the main and the secondary scarp of the landslide.

3.1 The geolithological features of the area affected by the landslide

An approximately 3-4 m thick deposit of terrigenous, poorly stratified travertine is located at the summit of the narrow ridge where the surface rupture of the landslide begins. This rests on a very heterogeneous, clastic deposit, belonging to the sedimentary cycle closing the Bastardo Basin: these are silt, silt-clay and sandy sediments associated with minute conglomerates. Levels and lenticles of lignitiferous clays combine with the aforementioned lithotypes at the foot of the slope. Contact between the clastic sediments and the bedrock, represented by the turbidites in flysch facies of the Marnoso-Arenacea Formation which continually is outcropping on the hydrographic right-hand side of the T. Puglia, is marked by a normal fault which can be linked, on a regional scale, to the one bordering the north-eastern slope of the Martani Mountains (Fig. 3). 
Table 1. Some index properties and mechanical characteristics of three samples of the soils affected by the Barattano landslide.

\begin{tabular}{ccccccccccc}
\hline $\begin{array}{c}\text { Borehole }- \\
\text { Sample }\end{array}$ & Deep $(\mathrm{m})$ & $\begin{array}{c}\gamma_{\mathrm{NAT}} \\
\left(\mathrm{g} / \mathrm{cm}^{3}\right)\end{array}$ & $\begin{array}{c}\gamma_{\mathrm{S}} \\
\left(\mathrm{g} / \mathrm{cm}^{3}\right)\end{array}$ & $W n$ & $W I$ & $W p$ & $I p$ & $\varphi^{\prime}$ & $\begin{array}{c}c^{\prime} \\
(\mathrm{kPa})\end{array}$ & $\varphi_{r}$ \\
\hline $\mathrm{S}_{2}-\mathrm{C}_{1}$ & $4-4.50$ & 2.11 & 2.73 & 22.08 & 50.6 & 19.9 & 30.7 & $19.8^{\circ}$ & 34.0 & \\
$\mathrm{~S}_{2}-\mathrm{C}_{2}$ & $11.50-11.80$ & 2.04 & 2.71 & 26.82 & 34.6 & 25.1 & 9.5 & $35.0^{\circ}$ & 8.0 & \\
$\mathrm{~S}_{3}-\mathrm{C}_{1}$ & $4-4.50$ & 2.08 & 2.76 & 26.11 & 55.6 & 21.2 & 34.4 & $17.5^{\circ}$ & 39.0 & $9.6^{\circ}-12.5^{\circ}$ \\
\hline
\end{tabular}

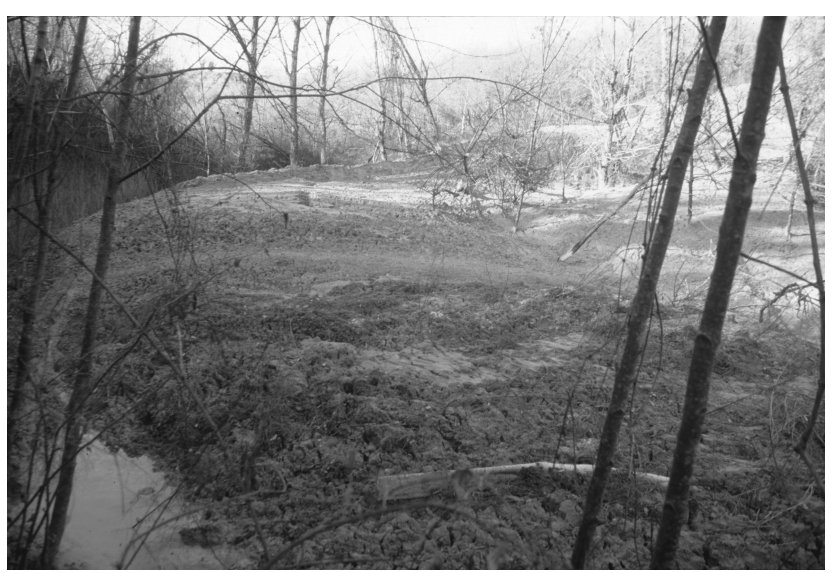

Fig. 9. In the terminal part of the landslide, the flow involves the river-bed of torrent Puglia, often producing an obstruction of the stream cross section.

\subsection{A geognostic investigation}

Following a geological survey of the surface of the landslide area in the spring of 1997, three cores were drilled along the main direction of movement which would be sent as far as $20 \mathrm{~m}$ below ground level. Two cores $\left(\mathrm{S}_{1}\right.$ and $\mathrm{S}_{2}$, Fig. 6) are located in the main body of the landslide and were equipped with open pipe piezometers $\left(\mathrm{P}_{1}\right.$ and $\left.\mathrm{P}_{2}\right)$; one $\left(\mathrm{S}_{3}\right)$ equipped with an inclinometer $\left(\mathrm{I}_{2}\right)$ was placed above the main scarp of the landslide. Another destructive hole was drilled alongside $\mathrm{S}_{2}$ in order to position another inclinometer $\left(\mathrm{I}_{1}\right)$.

Three undisturbed samples were taken from $S_{2}$ and $S_{3}$ and laboratory tests were carried out.

During the $S_{1}$ and $S_{2}$ drillings some Standard Penetration Tests (S.P.T.) were also performed at various depths.

\subsection{Stratigraphies of the drillings and S.P.T.}

The core drillings enabled the stratigraphic sequence to be reconstructed and the sliding surface to be calculated fairly closely (Fig. 10).

As far as approximately $11-12 \mathrm{~m}$ below ground level there are fine-grained soils which are mainly silt and silt-clay with moderately thick gravel and sandy gravel interbeds. The sequence is characterised by frequent lithological changes and shows evident textural differences at the base caused by flow now taking place.
Below the 11-12 m level, the sequence becomes compact and consists mainly of grey or blackish clays due to the presence of levels of lignite. Using a pocket penetrometer on various cores of this sequence continually gave high resistance levels.

The S.P.T. data, performed above and below the hypothetical slide plane, confirm the presence of two separate levels, consisting first of all of fairly thickened and reworked landslide material; the second from the surrounding soils not affected by the landslide.

\subsection{Laboratory tests}

Classification tests, as well as direct and torsion shear tests were made on the undisturbed samples in order to calculate the peak and residual resistance parameters (Table 1).

The grain-size analysis and references to the Casagrande plasticity curve (Fig. 11) show the soils consist mainly of clay and clay-silt, with a minimal part of sand, with mediumhigh plasticity. Direct shear tests gave values for the friction angle ranging between $17.5^{\circ}$ and $35^{\circ}$, with cohesion ranging from 8 to $39 \mathrm{kPa}$.

Two torsion tests were carried out on sample $C_{1}$ of the $S_{3}$ drilling under normal pressure ranging from 100 to $300 \mathrm{kPa}$ with a shear speed equal to $0.004 \mathrm{~mm} / \mathrm{min}$ in order to measure residual friction, which was found to be equal to $12.5^{\circ}$ and $9.6^{\circ}$. Both data agree with the empirical correlations in literature (Lancellotta, 1993), which refer to the values of the Clay Fraction $(\mathrm{CF})$ and to the Plasticity Index $\left(I_{P}\right)$.

\subsection{Inclinometer data}

During the geognostic investigation two inclinometer pipes were installed as far down as $-20 \mathrm{~m}$ below ground level: the first $\left(\mathrm{I}_{1}\right)$ was positioned in the middle-upper part of the main body of the landslide; the other $\left(\mathrm{I}_{2}\right)$ was placed above the main scarp of the landslide in an area which is at present stable. The latter was inserted in order to check any regression of the landslide. The data from inclinometer $\mathrm{I}_{2}$ did not show any movement in progress on the summit of the slope. The measurements from inclinometer $\mathrm{I}_{1}$, on the contrary, were concluded in January 1998, when the pipe broke $-14 \mathrm{~m}$ below ground level. The slide plain of the landslide movement can, therefore, be located at this depth, at the lithological change with the basal lignitiferous clays. The piezometer $\mathrm{P}_{2}$ placed alongside the inclinometer $\mathrm{I}_{1}$ in hole $\mathrm{S}_{2}$ also broke at the same depth and at about the same time. 


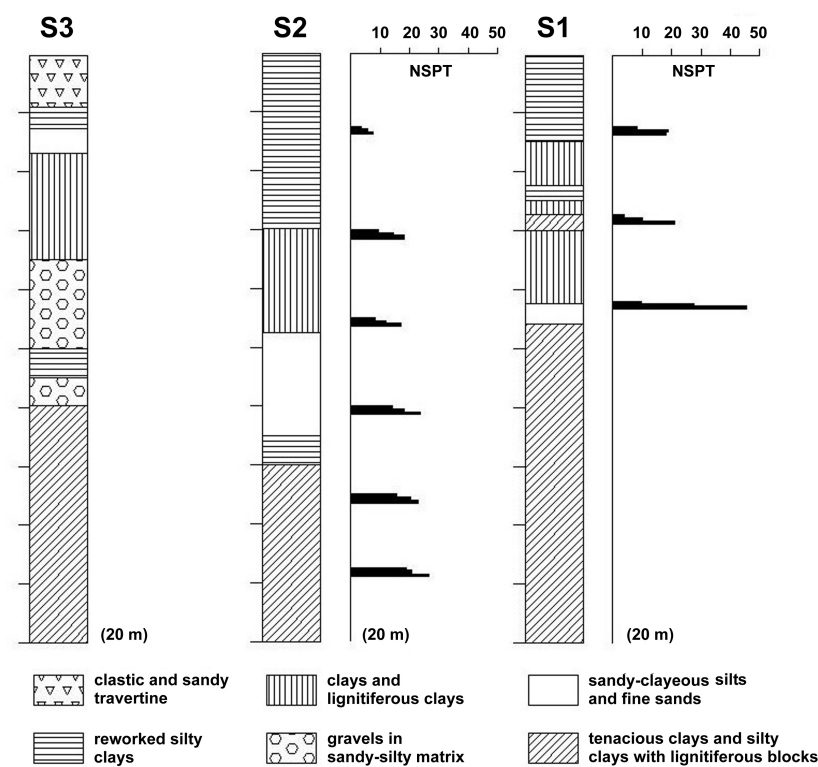

Fig. 10. Stratigraphic logs of the core drillings in the landslide of Barattano.

3.6 Hydrogeological features and piezometric measurements

Deep water circulation is hardly conditioned by the lithological sequence, consisting, as we said before, of a plate of terrigenous travertine, which is very permeable due to jointing but also due to its primary porosity. This plate overhangs a sequence in a lacustrine facies, consisting mainly of silt and silt-clay, with lenticles of sand and minute conglomerates inbetween: the latter being lithotypes with extremely variable permeability values.

Both the travertine plate and the upper clastic complex have a particularly high level of permeability, which gives rise (1) to perched water-tables with levels of lignitiferous clay at their base; (2) a high piezometric level is maintained near ground level throughout long periods during the year.

Two stand pipe piezometers were installed in the main body of the landslide and pushed $20 \mathrm{~m}$ down.

Measurements began immediately after installation (spring 1997) and continued for a year until the spring of 1998, when both shafts broke $\left(\mathrm{P}_{2}\right.$ at $-14 \mathrm{~m}$ below ground level and $\mathrm{P}_{1}$ at $-2 \mathrm{~m}$ ). While measurements were being taken, it was possible to see how the piezometric level descended just below ground level as far as a maximum of $-2.5 \mathrm{~m}$ in pipe $\mathrm{P}_{2}$. This proved that conditions of total saturation of the soils belonging to the clastic complex were maintained along the slope.

\subsection{Slope stability analysis}

To complete these investigations a stability check was made on the slope in back analysis, using limit equilibrium methods by means of SLOPE/W software (1995). A detailed topographical survey carried out along the main axis of the

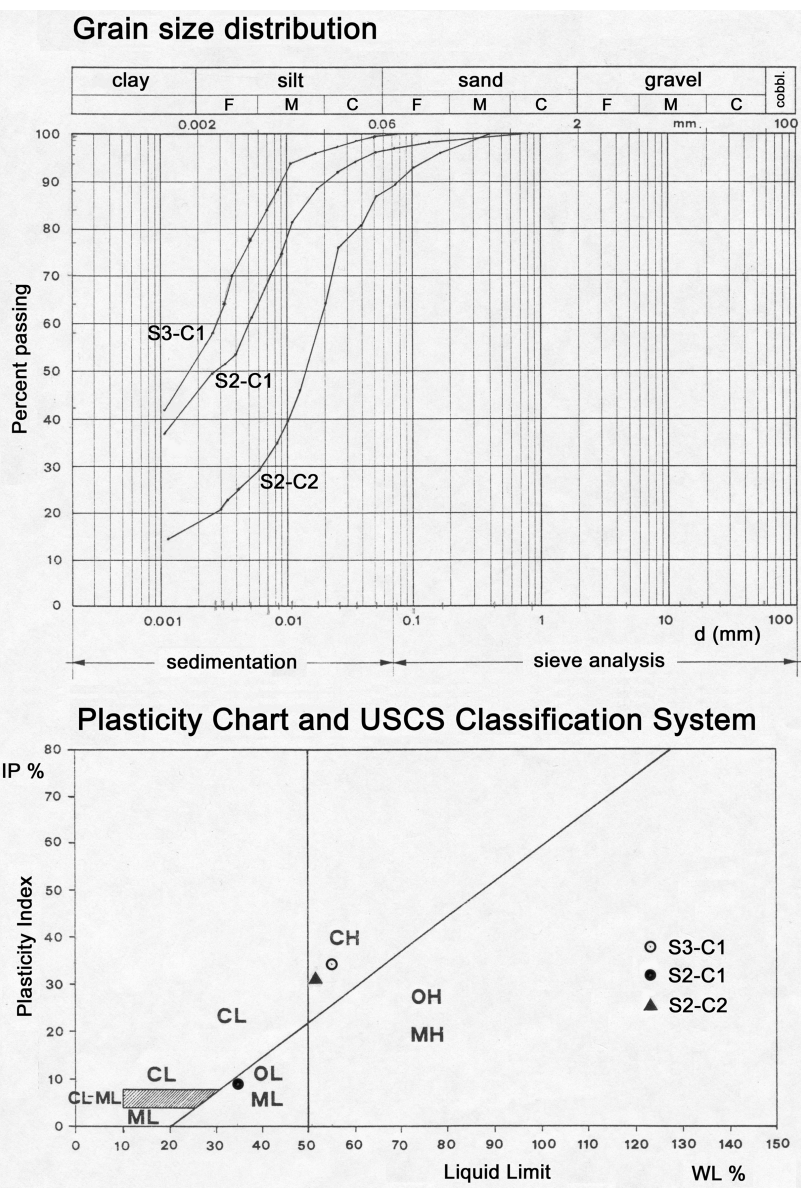

Fig. 11. Grain size distribution and USCS classification of the soils involved in the Barattano landslide.

movement itself, using inclinometer and stratigraphic data together with the laboratory tests, identified the geometry of the landslide movement (Fig. 12).

A first check assumed a piezometric surface close to ground level, as indicated by measurements made up to the spring of 1998. The geotechnical parameters used were: $\gamma_{\mathrm{NAT}}=2.08 \mathrm{t} / \mathrm{m}^{3} ; \varphi_{r}=12.5^{\circ}$. The safety factors proved lower than the unit. Then further checks imposed a piezometric level at approximately half-way down the main body of the landslide: in this case the safety factor always gave results above the unit, indicating a substantial slope stability under non-saturated conditions.

This proves that only the almost total saturation of the clastic deposits creates the conditions which will start movement.

As illustrated previously, saturation of the deposit is conditioned and encouraged in the site under study by the lithological sequence, which presents a very permeable plate of terrigenous travertine at the top, with a continuous groundwater, capable of creating conditions for landslide movement to continue.

A further stability check, made imposing a safety factor $F_{s}=1$, enables a theoretical value of the angle of friction actually set in motion equal to $13.5^{\circ}$, to be obtained. This 


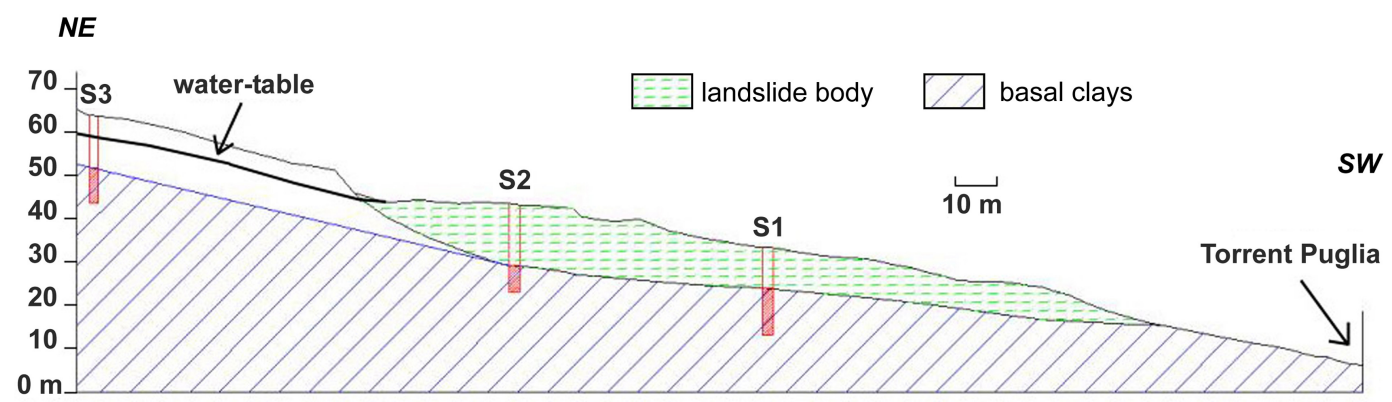

Fig. 12. Longitudinal section of Barattano landslide with the location of the core drillings $\left(S_{1}, S_{2}, S_{3}\right)$ and the hypothetical position of the sliding surface, presumably at the lithological change with the basal clays of the local stratigraphic sequence.

is slightly higher than, although basically in accordance with the residual one measured in the laboratory.

\section{Discussion}

The Barattano landslide, which involves the left-hand slope of the valley of the torrent Puglia, may be considered representative of a situation which is particularly common not only within the Bastardo Basin (Umbria), but also in general, within the other Apenninic intermontane basins in central Italy (in terms of type, factors and causes of the movement and in terms of linked conditions of risk).

The study of mass movement and the design of appropriate remedial measures are of great importance in terms of prevention and mitigation of geologic-hydraulic risk in Apenninic intermontane basins.

Here the presence of mainly fine-grained clastic sediments in a continental facies often produces both complex and composite types of landslides (such as rotational slides - flows).

The sediments involved in the landslide movement belong to the clastic deposits in the river-marsh facies of the Bastardo Basin and consist of a heterogeneous sequence of lithotypes including clays and conglomerates. An approximately 3-4 m thick plate of terrigenous travertine outcrops at the top of this sequence.

The spatial and vertical heterogeneity of the stratigraphic sequence, the different particle sizes of the clastic sediments and the geometric relationships between the lithosomes also influence the hydrogeological features of the mass, as a result of the frequent, rapid variations in permeability of the various levels which permit interstitial pressures to arise where the various lithotypes come into contact with each other.

In the case in question, the flow of the main body of the landslide causes the frequent obstruction (partial or total) of the torrent Puglia, with the temporary formation of a backwater and the consequent conditions of risk. The latter are linked to the presence a little further downstream of a provincial road bridge and various minor crossings with an inadequate span to permit exceptional flow rates, which could be caused by a sudden fall of the main landslide body and the formation of an anomalous flood wave.
As regards, however, the subject for more general research, i.e. the liability to landslides in the Villafranchian of the Apenninic intermontane basins in central Italy, with particular reference to the damming of the river bed caused by landslides, research will include the analysis of similar situations of landslide dams with the aim of working out a forecast model, which will permit the zoning of the territory in terms of:

- the possibility and probability of river bed damming due to landslides;

- the definition of possible scenarios deriving from the damming itself.

\section{Conclusions}

From all this arises the need for interventions which will stabilise the landslide area of Barattano. A relatively superficial slide surface was located at approximately $14 \mathrm{~m}$ below ground level. The data collected have enabled the geometry, kinematics and dynamics of the landslide movement to be identified.

The analysis on the limit equilibrium, carried out under different conditions of saturation of the clastic deposit, have shown that the conditions to start the landslide movement exist only with a piezometric level close to the surface. The friction angle calculated as being necessary for the phenomenon to develop coincides substantially with the residual one actually measured in the laboratory on an undisturbed sample.

Now that the essential lines of the kinematics and dynamics of the landslide movement have been identified, future research, as far as the Barattano landslide is concerned, will consist of:

- a more precise definition of the conditions of geological and hydraulic risk linked to the obstruction of the torrent;

- the definition of a project for the landslide area, which will aim to prevent future possible damming of the river bed of the torrent Puglia. 
Acknowledgements. The authors wish to sincerely thank Regione Umbria, for financing geognostic investigations in the Barattano Landslide, and M. Jaboyedoff, for the critic review of the manuscript.

\section{References}

Barchi, M., Brozzetti, F., and Lavecchia, G.: Analisi strutturale e geometrica dei bacini della Media Valle del Tevere e della Valle Umbra, Boll. Soc. Geol. It., 110, 65-76, 1991.

Brown, W. M. III, Cruden, D. M., and Denison, J. S.: The Directory of the World Landslide Inventory, U.S. Geological Survey Openfile Report 92-427, 216 p., Appendix 19 p., 1992.

Cencetti, C., Conversini, P., Ribaldi, C., and Tacconi, P.: Fenomeni di sbarramento naturale d'alveo nei corsi d'acqua dell'Appennino centrale, Proc. of International Congress "La prevenzione delle catastrofi idrogeologiche: il contributo della ricerca scientifica" (Alba, 5-7 November 1996), 1, 397-407, 1996.

CNR (AA.VV.): Structural model of Italy and gravity map, Vol. 3 of
"Progetto finalizzato Geodinamica: Risultati finali" (QRS-114), 9 maps at scale of 1:500 000, Firenze, 1991.

Cruden, D. M. and Varnes, D. J.: Landslide types and processes, in: Landslides: Investigations and Mitigation, Transportation Research Board, Special Report 247, edited by Turner, A. K. and Schuster, R. L., 36-71, 1996.

GE.MI.NA.: Ligniti e torbe dell'Italia continentale. Il Bacino Tiberino. Giacimento di Bastardo, Pubbl. Soc. Geomineraria Roma, Ed. ILTE, Roma, 1963.

Gregori, L.: Il Bacino di Bastardo: genesi ed evoluzione nel quadro della tettonica recente, Boll. Soc. Geol. It., 105, 173-184, 1988.

Lancellotta, R.: Geotecnica, Zanichelli Editore, Bologna, 1993.

Senneset, K. (ed.): Landslides, Proc. of the 7th International Symposium on Landslides, 17-21 June 1996, Trondheim, Norway, 1992 p., 1996.

SLOPE/W: Rel. 3, GEO-SLOPE International Ltd., Calgary, Alberta, Canada, 1995.

WP/WLI: A suggested method for describing the activity of a landslide, Bull. Int. Ass. for Eng. Geol., 47, 53-57, 1993 a.

WP/WLI: Multilingual Landslide Glossary, BiTech Publishers, Richmond, British Columbia, Canada, 59 p., 1993 b. 